\title{
RELIGION FOR NATURALISTS AND THE MEANING OF BELIEF
}

\author{
NATALJa Deng \\ YONSEI UNIVERSITY
}

\begin{abstract}
This article relates the philosophical discussion on naturalistic religious practice to Tim Crane's The Meaning of Belief: Religion from an Atheist's Point of View, in which he claims that atheists can derive no genuine solace from religion. I argue that Crane's claim is a little too strong. There is a sense in which atheists can derive solace from religion and that fact is worth acknowledging (whether or not this counts as 'genuine' solace).
\end{abstract}

\section{INTRODUCTION}

There are naturalists who feel an affinity with some religion, perhaps because they have been brought up in it, or perhaps because they are close to people who belong to it, or for some other reason. This phenomenon raises some interesting philosophical questions. How should we think of the role religious doctrines play in religion, and to what extent can those who reject religious beliefs enter into aspects of the religious life? Thinking about these leads one to consider the prior question of what it is that demarcates religion from other endeavors. Talk of 'naturalistic religious practice' implies both that there is an intelligible distinction between naturalism and religion in theory, and that there is some middle ground between the two in practice.

The aim of this article is to relate the philosophical discussion on naturalistic religious practice to Tim Crane's conception of religion and to his claim that atheists can derive no genuine solace from religion. I'll argue that there is a sense in which atheists can derive solace from religion, and that that fact is worth acknowledging (whether or not this counts as 'genuine' solace).

The main aim of The Meaning of Belief is to correct what Crane sees as shortcomings in the New Atheists' conception of religion (where by 'New Atheists', he 
means such writers as Richard Dawkins, Daniel Dennett, Sam Harris, Christopher Hitchens, and A. C. Grayling). ${ }^{1}$ As will become clear, I find Crane's conception of religion interesting and accurate to a large extent (I say a bit more about what I mean by this in section 3). But I'd like to emphasize that the value of the book as a corrective measure to the New Atheist movement is not my topic here; i.e. I'm not discussing the extent to which Crane's critique of the New Atheists succeeds. What follows is intended to be compatible with the New Atheists' writings containing a wealth of important insights. I'm commenting merely on the relation between Crane's conception of religion and naturalistic religious practice.

Let me start with some terminological remarks. By 'naturalism' I mean the view that there are no supernatural aspects to reality. Naturalism implies atheism, which is the claim that the theistic God does not exist. By 'theism', I mean the view that there is a God who is omniscient, omnipotent, and omnibenevolent, who created the world, and who is still actively involved in the world. I won't attempt to define 'supernatural', but I mean to include at least all claims about entities like gods or angels, and/or about the actions of such entities, like creation, miracles, or salvation, and/or about states of affairs involving holiness or heaven or hell.

Section 1 outlines Crane's conception of religion and his critical remarks on the possibility of 'atheistic religion'. Section 2 develops a version of religious fictionalism that can function as a basis for naturalistic religious practice, defends it from objections and recommends it over an alternative version. Section 3 returns to Crane's position. The upshot will be that there is a sense in which naturalists (including atheists) can derive solace from religion, and that this sense is all the more significant if one takes on board Crane's claim that religious belief is inherently paradoxical, which I'll provide some support for.

\section{THE RELIGIOUS IMPULSE AND IDENTIFICATION}

Crane acknowledges that one may well wonder at the outset what is meant by 'religion'. He points out that few things can be rigorously defined, and that there is likely to be no single essence of religion, but proposes that we think of the phenomenon as follows. Religion is "a systematic and practical attempt

1 Tim Crane, The Meaning of Belief: Religion from an Atheist's Point of View (Harvard Univ. Press, 2017). 
by human beings to find meaning in the world and their place in it, in terms of their relationship to something transcendent". ${ }^{2}$ One of these transcendent entities is the God of Western theism.

This is the phenomenon Crane is offering a conception of. The conception has two key ingredients: the religious impulse, and identification. By 'religious impulse, Crane means a belief (or the tendency towards forming a belief) with a certain complex content. Quoting William James, he says this is the belief 'that there is an unseen order, and that our supreme good lies in harmoniously adjusting ourselves thereto.' It's the belief that "this can't be all there is; there must be something more to the world", something that gives life as a whole meaning. ${ }^{4} \mathrm{He}$ also calls this belief in the transcendent. This belief gives the believer's life meaning because it is a belief in an unseen order, alignment with which makes life as a whole meaningful. So it's a belief about what the world is like, but one with important practical implications, regarding the behaviors that are likely to produce alignment with that unseen order.

Crane thinks this notion of the religious impulse differs in several key ways from the New Atheists' understanding of religious belief. First, the content of the religious impulse is not intended as a hypothesis in the scientific sense. It's not intended to provide an explanation by fitting an explanandum into a general pattern, and/or by relating it to something simpler and more intelligible. ${ }^{5}$ Secondly, according to Crane, the content of the religious impulse is inherently mysterious. There are inbuilt limits to how intelligible that unseen order can become to us. (I return to these claims in section 3.)

The second ingredient in Crane's conception of religion is the element of identification, which he takes to be about religious practice. He takes the key features of religious practice to be repetition, i.e. the historical dimension of religious practice, and a social dimension, i.e. the fact that one typically engages in these actions with other people. 'Identification' is intended to stand for both of these features.

2 Crane, The Meaning of Belief, 6.

3 William James, The Varieties of Religious Experience: A Study in Human Nature (Longmans, Green and Co, 1902), 53.

4 James, The Varieties of Religious Experience, 38.

5 For some worries about the view of science implicit in this, see Arif Ahmed, "The Meaning of Belief: Religion from an Atheist's Point of View, by Tim Crane", Mind 127, no. 508 (2018): 1265. 
Note that Crane prefers talk of the transcendent to talk of the supernatural. At least he rejects the New Atheists' use of the term 'supernatural' as at once too sophisticated ("religious believers need not operate with the clearcut idea of the supernatural attributed to them by today's philosophers and scientists") and too simplistic ("the idea of God is not simply the idea of a supernatural agent who made the world"). ${ }^{6}$ But as I'm using 'supernatural', it is not at all clear-cut (though useful nonetheless). Moreover, while theism is, amongst other things, a thesis about a supernatural agent, this is compatible with there being more to its content, as well as with the possibility that its content is quite complex (see section 3 ).

Consider now Crane's stance on the possibility of naturalistic religious practice. Even though it is not his main concern, Crane touches on this topic at various points in the book. For example, when commenting on Ronald Dworkin and Alain de Botton, he makes two points. The first is that whatever each of these authors is proposing, it shouldn't be called Religion (as in Dworkin's Religion without God, or De Botton's Religion for Atheists), since neither proposal involves the religious impulse, one of the key ingredients of religion. ${ }^{7}$ I agree: what these authors are proposing involves a rejection of the supernatural (and of the transcendent). That feature will make what they are proposing importantly different from the original phenomenon. And it does matter that we not stretch terms ('religion') beyond the limits of usefulness. So what these writers are proposing can't literally be an atheistic religion; nor could anyone else propose anything that is best described as such.

Crane's second point, though, is the following:

I share these thinkers' opposition to the New Atheists. But I don't think an atheist can find genuine solace in religion. There are things to admire in the religious traditions in the world, but it is one thing to admire aspects of a religion and another to try to adopt its practices without believing its doctrines. ${ }^{8}$

While there may be much to disagree with in De Botton's and Dworkin's proposals (who are, after all, Crane's targets in this passage), it is worth situating these remarks with respect to the recent philosophical literature on the topic.

6 Crane, The Meaning of Belief, 12-13.

7 Ronald Dworkin, Religion without God (Harvard Univ. Press, 2013); Alain Botton, Religion for Atheists (Penguin, 2012).

8 Crane, The Meaning of Belief, 23. 
When we zoom into the practical grey area between religion and naturalism, we do find room for naturalistic religious practice.

I should note right away that Crane may not disagree with anything that follows, since he allows that there can be people who participate in religious practices without any sense of the transcendent, i.e. without the religious impulse. ${ }^{9}$ He also suggests that many Jews and Christians are deeply embedded in their respective religious traditions, while nevertheless lacking what Thomas Nagel calls 'the religious temperament', which is the need for an aspiration "to live not merely the life of the creature one is, but in some sense to participate through it in the life of the universe as a whole" ${ }^{10}$ For Crane, these Jews and Christians are religious in a sense, even though they lack a religious temperament, and even though many of them also lack the religious impulse.

What, then, is the sense in which they are religious? And, is it really the case that none of them can find solace in religion, when "[i]t is of supreme importance in their lives that they are [for example] Jews, that what they are doing is what their parents and grandparents did, and that their lives would not make any real sense without it"? ${ }^{11}$

\section{RELIGIOUS FICTIONALISM}

To get clearer on what is available to naturalists here, let's consider the position known as fictionalism, which has been deployed in a variety of philosophical domains. One particular variety of fictionalism will be most relevant to our purposes. ${ }^{12}$

9 Crane, The Meaning of Belief, 106.

10 Thomas Nagel, Secular Philosophy and The Religious Temperament (OUP, 2010), 5.

11 Crane, The Meaning of Belief, 52.

12 For some recent applications of fictionalism to the religious domain, see e.g. Peter Lipton, "Science and Religion: The Immersion Solution", in Realism and Religion: Philosophical and Theological Perspectives, ed. Michael Scott and Andrew Moore (Taylor and Francis, 2007); Benjamin Cordry, "A Critique of Religious Fictionalism", Religious Studies 46, no. 1 (2010); Andrew Eshleman, "Religious Fictionalism Defended: Reply to Cordry", Religious Studies 46, no. 1 (2010); Victoria Harrison, "Philosophy of Religion, Fictionalism, and Religious Diversity", International Journal for Philosophy of Religion 68, no. 1-3 (2010); Christopher Jay, "The Kantian Moral Hazard Argument for Religious Fictionalism", International Journal for Philosophy of Religion 75, no. 3 (2014); Natalja Deng, "Religion for Naturalists", International Journal for Philosophy of Religion 78, no. 2 (2015); Robin Le Poidevin, "Playing the God Game: The Perils of Religious Fictionalism", in Alternative Concepts of God: Essays on the Metaphysics 
Take an approach to the language in a given domain that combines the following three claims. (1) The sentences in that domain are truth-apt (they can be true or false) and ordinarily express beliefs; (2) at least some of them are about what they seem to be about - that is, they are not entirely figurative or metaphorical; but (3) our attitudes towards these sentences need not be truth-normed. Although the sentences in question purport to describe reality, our attitude towards them need not depend on their truth or falsity. Our attitude can be one of non-doxastic acceptance. This is supposed to be a distinctive kind of state of commitment that doesn't involve belief. The value involved in believing sentences in this domain is independent of whether our attitudes are non-doxastic. Elsewhere, I have called this view 'Weak Evaluative Fictionalism' or WEF. ${ }^{13}$ (Note that religious WEF can also be explored in connection with agnosticism. But the focus here will be on its uses for understanding naturalistic (including atheistic) religious practice.) I will call the conjunction of (1) and (2) a realist approach to the language in a given domain. ${ }^{14}$

In the background of religious WEF and of realism about religious language, is the assumption that there are such things as sentences with a religious subject matter, and that it makes sense to enquire into their meaning. Examples of religious sentences might include 'For God so loved the world that he gave his one and only Son', 'He will come again in glory to judge the living and the dead', or 'God is our refuge and strength. This basic assumption contrasts with approaches such as those of William Alston and (according to some) Ludwig Wittgenstein. ${ }^{15}$ For example, Wittgenstein in some places implies that the meaning of religious utterances ('There will be a Last Judgement') is so radically context-dependent that their meaning cannot be approached by thinking about the meaning of religious sentences. He contends that when a religious person says 'There will be a Last Judgement' and a non-religious person says 'There will not be a Last Judgement', they do not contradict one another.

of the Divine, ed. Andrei A. Buckareff and Yujin Nagasawa (OUP, 2016); Finlay Malcolm, "Can Fictionalists Have Faith?", Religious Studies 54, no. 2 (2018); Michael Scott and Finlay Malcolm, "Religious Fictionalism", Philosophy Compass (forthcoming).

13 Deng, "Religion for Naturalists".

14 Some authors include in the definition of a 'realist' semantics for a language the claim that some of the sentences in question are true. As I'm using the term, that is not part of it.

15 See Michael Scott, "Religious Language", Philosophy Compass 5, no. 6 (2010). 
Any plausible approach to the semantics of religious language has to take into account the considerable role that context plays in determining the meaning of religious utterances. Nonetheless, it seems plausible that religious sentences, like other sentences, have some stable semantic content. After all, we seem able to communicate about religious matters, and to voice diverging opinions about them.

Realism about religious language also opposes expressivist and reductionist approaches to the semantic project by maintaining that religious sentences are ordinarily used to express beliefs (rather than merely plans, attitudes, or emotions), and that at least some religious sentences are about what they seem to be about. At least some religious sentences are not just codified ways of talking about aspects of the natural or social world. WEF's distinctive addition to this is the claim that the value associated with the religious domain is independent of whether we believe the sentences in question, or merely non-doxastically accept them.

That can sound quite incredible. Consider such values as solace or hope. How can the naturalist derive any such thing from non-doxastically accepting religious sentences? Some of these sentences state that there is reason to think that there is an after-life, during which one will see one's loved ones again. Similarly, some others state that there is a divine being who guides all that happens in the universe, and who deeply cares for each of us. If truth and falsity make no difference to the acceptability of these sentences, then when do they matter? Surely the values in question are inaccessible to naturalists.

One reaction one might have to these questions is to weaken religious WEF somewhat. Perhaps not all of the value accessible to religious believers is independent of belief, but some of it is. The problem with this weaker form of religious WEF is one that also afflicts the stronger one: it's unclear how one can non-doxastically accept anything. Non-doxastic acceptance is intended to be acceptance in all 'ordinary', 'non-critical' contexts. Roughly, the idea is that as long as one is not doing philosophy, or otherwise critically probing one's beliefs, one assents to the sentences in question, but in 'critical contexts', one dissents. Unfortunately, it is doubtful that there is a principled distinction between 'critical' and 'non-critical' contexts. ${ }^{16}$ All we can say is that in any

16 See Zoltán G. Szabó, "Critical Study of Mark Eli Kalderon (ed.) Fictionalism in Mataphysics", Noûs 45, no. 2 (2011). 
given context, a variety of considerations are potentially relevant, and we usually choose to bracket some but not others. Since non-doxastic acceptance is defined as assent in all but 'critical' context, this is a serious problem for WEF, even in a weakened form. This means that WEF does not achieve its aim: it doesn't really offer a principled way for naturalists to use religious language, in a way that allows them to live just as if the religion were true. Assuming that we want to avoid periodic wavering, hypocrisy, and mental fragmentation, we have not yet found a viable basis for naturalistic religious practice.

But there is such a basis. If we want, we can still call this a version of religious fictionalism (though not of WEF). ${ }^{17} \mathrm{~A}$ note of caution before we proceed: what follows is a description of a fictionalist basis on which naturalists can engage in religious practice. The kind of naturalist I'm addressing feels an affinity with some religions, or with a particular religion. This suggests that in some sense they think religious practice has some value. For my purposes, we can just take this to mean that they think religious practice achieves something that they value, such as inspiration, comfort, personal or spiritual or moral growth, a sense of purpose, or a sense of community. So I'll assume, for the purposes of this discussion, that such things are available to some people by religious means. I won't, however, assume anything about whether religion also has dis-value, or about whether that dis-value outweighs any value it may have, either in the case of believers or even in the case of the naturalist practitioner I'll describe. A fortiori, it's no part of my proposal that naturalists who don't feel such an affinity should become religious practitioners.

Unlike (perhaps more properly so-called) fictionalist positions in many other domains, the version that best fits the religious domain does not make use of the notion of non-doxastic acceptance. It does not aim to allow the naturalist to live a life that is indistinguishable from a believer's in all but 'critical contexts'. Instead, it simply emphasizes the possibility of treating a religious tradition and its texts like a story, and of engaging in a game of makebelieve. ${ }^{18}$ For example, when taking part in a religious service, one immerses

17 It was pointed out by referees that it makes sense to retain the 'fictionalist' label for the view I'm proposing. I wouldn't insist on the label though.

18 Richard Joyce, when advocating fictionalism about morality, talks of a spectrum of stances (Richard Joyce, The Myth of Morality (CUP, 2001), Ch. 7). At the near end of the spectrum, there is the stance we all take with respect to fiction, for example when we tell a story or otherwise engage with one. At the far end, there is non-doxastic acceptance. The position 
oneself in a story, and becomes an actor within the fictional world of that religion's world view. As Le Poidevin has pointed out, the mere experience of the religious service can have the power to engage one's emotions,

to the extent that a religious service is capable of being an intense experience. The immediate object of our emotions is the fictional God, but there is a wider object, and that is the collection of real individuals in our lives. In the game of make-believe (for example, the Christian one), we are presented with a series of dramatic images: an all- powerful creator, who is able to judge our moral worth, to forgive us or to condemn, who appears on Earth in human form and who willingly allows himself to be put to death. What remains, when the game of make-believe is over, is an awareness of our responsibilities for ourselves and others, of the need to pursue spiritual goals, and so on. ${ }^{19}$

In a similar way, the naturalist can take part in a variety of religious rituals and forms of worship.

One of the objections often raised for fictionalism in this and other domains is this: isn't the fictionalist practitioner constantly expressing beliefs they don't have, and thereby lying to those around them? This can seem particularly worrying in the religious case, given the intimate role that religion plays in many believers' lives. But it's important to keep in mind that on the version of fictionalism proposed, the naturalist is not acting just as if the religion were true. They are not hiding their rejection of the supernatural. Rather, they are consciously and transparently engaging with a religious tradition by treating it and its texts as a story. Religious practices are for them tools for creating certain atmospheres - namely ones that will instill a sense of something sacred.

Le Poidevin defends a different form of religious fictionalism from the one proposed here. His version, like WEF, is more susceptible to the objection discussed in the previous paragraph. On Le Poidevin's version, the truth-conditions of religious sentences are as follows: "any given [religious sentence] $p$ is true if and only if it is true in the theological fiction that $p$ " ${ }^{20}$ Le Poidevin thinks that this version, involving a 'fictionalist semantics', is preferable to the one advocated here, which accepts a realist semantics and adds talk of a distinctive fictionalist attitude of make-believe:

I'm describing is located on the near end of Joyce's spectrum, near more familiar activities of make-believe (see Deng, "Religion for Naturalists").

19 Robin Le Poidevin, Arguing for Atheism: An Introduction to the Philosophy of Religion (Routledge, 1996), 119.

20 Le Poidevin, Arguing for Atheism, 178. 
[I]t is not clear that the attitude is rationally sustainable independently of the corresponding semantics. On the other hand, treating theological statements as if they were true clearly fits comfortably with the supposition that they are in fact fictional. That, arguably, is the purer position. ${ }^{21}$

Thus, according to Le Poidevin, it makes more sense to combine the fictionalist attitude of make-believe with a 'fictionalist semantics'.

I have two related worries about this. The first is that, as Le Poidevin is no doubt aware, the fictionalist semantics proposed (according to which e.g. 'God gave his only Son' is true if and only if 'according to Christianity/the theological fiction, God gave his only Son') fares rather badly as a semantics for the religious sentences as used by believers. This is not what religious believers mean when they use religious sentences. Religious believers are making statements about the world, not about the theological fiction advocated by their religious institution. Le Poidevin's position seems to be that those who take a realist view of the semantics (including religious believers, but also atheists and agnostics) are right about the semantics of religious sentences as used by them, while fictionalists are right about the semantics of religious sentences as used by themselves. ${ }^{22}$

But that's a bit strange. Suppose a religious fictionalist (of the kind Le Poidevin is interested in) encounters some non-fictionalists, either in the context of a religious service, or while talking about religion. Of course, the fictionalist can use the religious sentences to mean something different from everyone else, but presumably they can't deny that they understand what the others are using them to mean. After all, there is nothing unclear about using the sentence 'God loves us' to say that God loves us (as opposed to that according to some theological fiction, God loves us). Given that the fictionalist understands this, it seems odd to decide to ignore this straightforward meaning and instead use the same sentence to mean something entirely different. Why not use a different sentence (such as, 'according to some theological fiction, God loves us') to mean that according to some theological fiction, God loves us? This worry relates back to the objection discussed above. It's hard to imagine why the fictionalist would adopt such a non-standard semantics, other than for the reason that they want to blend in and give the impression

21 Le Poidevin, Arguing for Atheism, 181.

22 Le Poidevin, "Playing the God Game", 182. 
of more agreement than there really is. Better to accept the realist semantics, and just to adopt a fictionalist attitude (of make-believe) — which, after all, is what really matters to Le Poidevin's fictionalist too.

The second worry is more serious, because it concerns the very ability of Le Poidevin's fictionalist to adopt the fictionalist attitude in question. On the 'fictionalist semantics' proposed, there seems to be no room for a fictionalist attitude. 'God gave his only Son' is simply true, on that semantics, because it means that according to the Christian theological fiction, God gave his only Son. So there is nothing for the fictionalist to adopt a fictionalist attitude towards: it wouldn't make sense to make-believe that according to Christianity, God gave his only Son. That's just something we all believe and know to be the case. ${ }^{23}$

Let's return to the version of fictionalism proposed here. There is even the possibility of a fictionalist version of prayer. Elsewhere I have called this 'make-believe prayer'. ${ }^{24}$ Le Poidevin too emphasizes this possibility. He concedes that there are kinds of prayer that are not available to the fictionalist, for example petitionary prayer (asking God for things) or seeking companionship with God. But he suggests that the fictionalist may still be able to use prayer to align their will with what they imagine would be God's will. Suppose the idea of God represents for them an ideal of perfect love.

[The fictionalist] might find it helpful to voice, in her head, her own thoughts, as if they were addressed to another person, and imagine what someone motivated only by love would say in response. And, without there being any actually hallucinatory experience, answers may come to her as if they did not have their origin in her own thoughts. Phenomenologically, this could have a great deal in common with the experience of prayer that many realists have. ${ }^{25}$

It might seem strange to want to dedicate feelings of gratitude or humility to a being one believes is not there. But if one resonates with the idea of an all powerful, all-loving creator who is able to hear and listen to one's concern, then it can make experiential sense to momentarily dedicate feelings of gratitude, or humility, to that fictional God. In Petru Dumitriu’s words: "I cast my

23 Scott and Malcolm, "Religious Fictionalism" point to further problems with Le Poidevin's version of religious fictionalism. Actually, as they also note, many of these problems are not specific to the application of this kind of fictionalism to the religious domain.

24 Deng, "Religion for Naturalists".

25 Le Poidevin, "Playing the God Game", 187. 
gratitude into the void, I want to call out in the void. If there is no one there, I want to address myself to that strange absence". ${ }^{26}$

\section{MYSTERY AND OPTIMISM}

One can acknowledge the possibility of meaningful naturalist religious practice without losing sight of the distinction between religion and naturalism.

Recall the two key ingredients of religion according to Crane, the religious impulse, and identification (repetition and the social dimension). The religious impulse is a belief in the transcendent, an unseen order, alignment with which gives our lives meaning, while " $\mathrm{t}$ ] he element of identification consists in the fact that religion involves institutions to which believers belong and practices in which they participate". ${ }^{27}$

I said at the outset that Crane's conception seems accurate to a large extent. What do I mean by 'a large extent'? Here is one general point about the scope of what follows. Consider Arif Ahmed's review of Crane. Ahmed is commenting on the extent which Crane's critique of the New Atheists succeeds, and he argues that it does not. Interestingly, he prefaces his criticism with the following:

I can imagine many humane and thoughtful Jews, Christians and Muslims finding in this book an almost unimprovable articulation of their own approaches to faith. I myself have learnt, and I expect many atheists will learn, much more than I thought could intelligibly be said about what religious belief could and perhaps should be. What it is, is another question. ${ }^{28}$

To my mind, the first sentence implies that Crane has an accurate conception of the religion practiced by some people, namely those humane and thoughtful theists. I take myself to be focusing on just them; this is the scope of what follows. Let's call their version of theism humane theism. It might be nice to be able to offer some empirically grounded estimates of the size of this group, but I won't attempt that here. If it turns out to be a much smaller group than I imagine, so that this is a large concession towards the New Atheists, so be it. What follows is just about humane theism.

26 Petru Dumitriu, To the Unknown God (Au Dieu Inconnu) (Seabury Press, 1982), 106.

27 Crane, The Meaning of Belief, 23.

28 Ahmed, "The Meaning of Belief”, 1261. 
Let's now return to Crane's discussion of 'atheistic religion'. I said that he's right to point out that there can be no such thing. Dworkin's proposal lacks both elements of religion. De Botton's proposal aims to make room for the element of identification, but it leaves no place for the religious impulse - unsurprisingly, since that impulse is a belief the naturalist rejects. There can't literally be a naturalistic religion (nor an atheistic religion); a naturalist can't take over religion and its practices without altering its nature.

But we can see now that Crane's overall assessment isn't right: there is a sense in which a naturalist can find solace in religion (that is, in naturalistic religious practice). Not in the sense of the conviction, or even hope, of an afterlife or of an unseen order that provides for us and sees to it that justice is done in the end. ${ }^{29}$ Nor in the sense of knowing, or even hoping, that a divine being is listening to and caring for one's concerns in the present. What is available has to do not with (degrees of) belief, but merely with thoughts: the very thought of such an unseen transcendent order can elicit a positive emotional reaction. This is in principle no more puzzling than thoughts of disaster (such as one's house burning down) eliciting negative emotional reactions, even if one knows that these thoughts have nothing to do with reality. And though the reactions are momentary, one can choose to elicit them repeatedly. Compare this also to aesthetic experience. Music too elicits reactions only in a given moment, but people choose to consume it repeatedly.

Naturalistic religious practice, then, can involve both identification (in both the historical and social senses), and some connection to the (content of the) religious impulse. Though a naturalist rejects the belief in an unseen order, they can choose to repeatedly entertain thoughts of it, and to let specific religious stories about the nature of that unseen order engage them emotionally. Moreover, the naturalist practitioner can spend as much time within the religious game of make-believe as they choose. They can even include ideas and practices from different religious traditions. Theirs is a sui generis form of engagement with religion (though one that I think already exists).

29 I think it is possible, without irrationality, to wish for $p$ while disbelieving $p$; but I do not think the same holds for hoping that $p$ while disbelieving $p$ (cf Malcolm, "Can Fictionalists Have Faith?", 228; for further discussion see Einar Duenger Bohn, "The Logic of Hope: A Defense of the Hopeful", Religious Studies 54, no. 1 (2018)). Moreover, I do not think the naturalist practitioner necessarily needs to hope or wish that the religious story be true. One need not want a story to be true in order to find aspects of it beautiful or otherwise engaging. 
One could now insist that all this doesn't amount to solace in a substantial sense. Without getting distracted by quibbles over what counts as 'genuine' solace, the important point is that one shouldn't be too quick to dismiss the value of what is available to some naturalists in this way. This becomes even clearer if one reflects on what exactly is available to the believer at various points during their lives. Crane points out that the religious impulse is rather more complex than is often assumed. Talk of the afterlife is just as often an expression of a fragile hope as it is an expression of a comforting conviction. Crane also describes what he calls the essential paradoxicality of the content of the religious impulse, quoting Alfred N. Whitehead:

Religion is the vision of something which stands beyond, behind and within the passing flux of immediate things; something which is real, and yet waiting to be realized; something which is a remote possibility and yet the greatest of present facts; something that gives meaning to all that passes and yet eludes apprehension; something whose possession is the final good and yet is beyond all reach; something which is the ultimate ideal, and the hopeless quest. ${ }^{30}$

This point seems to me relevant to the question of how significant we should take naturalist religious practice to be, because it refines our picture of what is available to the believer. It's not just that the believer struggles with maintaining belief in the face of suffering, though that is a very real struggle. ${ }^{31}$ It's that, at least in many religious traditions, the very nature of the transcendent - and with it, the very nature of what it is one does when engaging with ideas about the transcendent - has to remain mysterious. It's not just beyond human understanding how, if God exists, the world can contain the suffering it contains. Ultimately, it's beyond human understanding even what it would be for God to exist. And when that is part of a story, the value of engaging with that story becomes to an additional degree independent of belief or hope. Part of what matters in religious practice is simply opening oneself up to the feeling of existential uncertainty, by repeatedly engaging with the very idea of the transcendent. ${ }^{32}$

30 Alfred N. Whitehead, Science and the Modern World (Free Press, 1967), 192.

31 This struggle is probably one that is not accessible to the naturalist (though see Le Poidevin, "Playing the God Game", 187, for the suggestion of a fictionalist counterpart).

32 It might be objected here that not all religious traditions involve mysticism, and that their interpretation should not overemphasize this element of mystery and paradoxicality. Crane an- 
One reason some naturalists might want to do this is that they too may include mystery somewhere in their world view, even if they don't connect that mystery to anything transcendent. That is, the world according to a naturalist may be mysterious in some secular sense (as Crane himself seems to suggest in places). ${ }^{33}$ If in addition, they find some religious story a beautiful reaction to that mystery, then they too can appreciate that story. But even if a naturalist finds no place for anything worth calling 'mystery' in their world view, if they feel an affinity with some religious tradition, they can still engage in that tradition's practices, and experience some of the same sense of the sacred as a believer might.

One other point from The Meaning of Belief is relevant here. Crane makes a distinction between what he calls 'pessimistic atheists' and 'optimistic atheists'. Pessimistic atheists (of which he says he is one) find the religious impulse intelligible and acknowledge that the transcendent would give life meaning of a kind it can never actually have. They also acknowledge that religious believers are able to appreciate religious art and music in a way no secular person can. Optimistic atheists, as Crane thinks of them, are inclined to disagree on both points. They think their experience of works of religious art shows that they too can fully appreciate them. Moreover, the Cranean optimistic atheist finds the religious impulse unintelligible. They think the idea of the 'enchantment' of the world, of the world really harbouring an unseen order that gives life as a whole meaning, is a kind of confusion. So they won't concede that a naturalist world view is in any sense bleak, because what the naturalist has rejected didn't make sense in the first place.

Religious fictionalism of the kind described here, and the naturalistic religious practice it grounds, have a distinctly optimistic flavor. But neither relies on the optimist's claim that the religious impulse is unintelligible, in the sense that there was never anything there to hope for. The religious impulse makes enough sense to be an object of hope, and the naturalist does not share that

ticipates this objection: "This is not to say that orthodox versions of Judaism, Islam, and Christianity should be regarded as mystical faiths, but only that they place certain epistemic limits on believers: that is, limits about what they can know" (Crane, The Meaning of Belief, 57). Admittedly, there is a difference between there being limits to what can be known (or said) and there being hardly anything that can be known (or said), and talk of an 'ultimate' mystery can mask a slide between these two claims. But it seems to me that in practice, the element of mystery Crane describes does play a central role even in orthodox versions of Western theistic religions.

33 E.g. Crane, The Meaning of Belief, 159. 
hope (see footnote 28). Since they believe there is no transcendent aspect to reality, they cannot, without periodic wavering or mental fragmentation, live just as if the religion were true, or even just as if it might be true. Naturalistic religious practice, on this version of religious fictionalism, is fundamentally different in nature from a believer's practice.

Nonetheless, as we've seen, the naturalist is able to access some experiences that are similar to those of the believer, and one reason for this does have to do with how intelligible the idea of the transcendent can become. The strange situation we are in with respect to the demarcation of religion is this. As Crane acknowledges (despite his criticism of the New Atheists' focus on cosmological elements), the religious impulse is a key feature of religion. Since naturalism is defined in terms of the belief(s) it rejects, the religious impulse lies at the heart of what separates religious believers from naturalists. And yet the content of the religious impulse is inherently paradoxical and ultimately has to remain mysterious. ${ }^{34}$

\section{CONCLUDING REMARKS}

The theme of this collection of articles, 'Philosophy, Religion, and Hope', is open to a variety of interpretations. The interpretation I've focused on is, what is the role that religious doctrine plays in religion, and to what extent can naturalists enter into aspects of the religious way of life? My aim was to relate the philosophical discussion on these questions to Tim Crane's The Meaning of Belief, especially his claim that atheists can derive no genuine solace from religion.

I've argued that while there are limits to naturalistic religious practice, there is an experientially significant remainder accessible to naturalists who feel so inclined. Whether or not this remainder involves anything properly describable as 'genuine' solace, it can be of enough value to the naturalist to be worth engaging in, and it need involve no mental fragmentation or hypocrisy. I've also suggested that there is a version of fictionalism that can underwrite this practice, on which one treats a religion as a story to be imaginatively entered into and brought to life. Moreover, the significance of this kind of activity is all

34 Is there a tension between this talk of mystery in the content of the religious impulse and taking a realist approach to the semantics of religious language? I am not sure there is: a stable semantic content is not the same as a definite or non-mysterious semantic content. 
the greater if one is prepared to take on board Crane's claim that religious belief is inherently paradoxical, for which I've provided some support.

A different way to interpret the theme 'Philosophy, Religion, and Hope' would be this: when it comes to matters of inter-religious dialogue, including dialogue between the religious and the non-religious, is there reason to be hopeful? And, can philosophy help? Though not an academic philosophy book, The Meaning of Belief demonstrates how philosophy can help. The book's closing sentences highlight the connection between these two ways of interpreting the theme:

The problems the world is facing are practical political problems, problems whose solutions need cooperation, coordination, and compromise. Any view about how atheists and theists should live together and interact must ultimately confront the fact that neither religion nor secularism is going to disappear. The least we can hope for is peaceful coexistence, while the most we can hope for is a kind of dialogue between those who hold very different views of reality. A genuine dialogue of this kind will be very difficult to achieve, but the first step must be for each side to gain an adequate understanding of the views of the other. ${ }^{35,36}$

\section{BIBLIOGRAPHY}

Ahmed, Arif. 2018. "The Meaning of Belief: Religion from an Atheist's Point of View, by Tim Crane”. Mind 127, no. 508: 1261-70. doi:10.1093/mind/fzy018.

Botton, Alain. 2012. Religion for Atheists. London: Penguin.

Bohn, Einar Duenger. 2018. “The Logic of Hope: A Defense of the Hopeful”. Religious Studies 54, no. 1: 107-116. doi:10.1017/S0034412516000469.

Cordry, Benjamin. 2010. "A Critique of Religious Fictionalism”. Religious Studies 46, no. 1: 77-89. doi:10.1017/S0034412509990291.

Crane, Tim. 2017. The Meaning of Belief: Religion from an Atheist's Point of View. Cambridge, MA: Harvard Univ. Press.

Deng, Natalja. 2015. "Religion for Naturalists". International Journal for Philosophy of Religion 78, no. 2: 195-214. doi:10.1007/s11153-015-9529-y.

35 Crane, The Meaning of Belief, 193.

36 This work was supported (in part) by the Yonsei Univ. Future-Leading Research Initiative of 2018 (2018-22-0100). 
Dumitriu, Petru. 1982. To the Unknown God (Au Dieu Inconnu). New York, NY: Seabury Press.

Dworkin, Ronald. 2013. Religion without God. Cambridge, MA: Harvard Univ. Press.

Eshleman, Andrew. 2010. "Religious Fictionalism Defended: Reply to Cordry". Religious Studies 46, no. 1: 91-96. doi:10.1017/S0034412509990333.

Harrison, Victoria. 2010. "Philosophy of Religion, Fictionalism, and Religious Diversity”. International Journal for Philosophy of Religion 68, no. 1-3: 43-58.

James, William. 1902. The Varieties of Religious Experience: A Study in Human Nature. New York, NY: Longmans, Green and Co.

Jay, Christopher. 2014. "The Kantian Moral Hazard Argument for Religious Fictionalism”. International Journal for Philosophy of Religion 75, no. 3: 207-32. doi:10.1007/s11153-013-9435-0.

Joyce, Richard. 2001. The Myth of Morality. Cambridge: Cambridge Univ. Press.

Le Poidevin, Robin. 1996. Arguing for Atheism: An Introduction to the Philosophy of Religion. London: Routledge.

-. 2016. "Playing the God Game: The Perils of Religious Fictionalism". In Alternative Concepts of God: Essays on the Metaphysics of the Divine, edited by Andrei A. Buckareff and Yujin Nagasawa, 178-94. Oxford: Oxford Univ. Press.

Lipton, Peter. 2007. "Science and Religion: The Immersion Solution". In Realism and Religion: Philosophical and Theological Perspectives, edited by Michael Scott and Andrew Moore, 31-46. Brookfield: Taylor and Francis.

Malcolm, Finlay. 2018. “Can Fictionalists Have Faith?”. Religious Studies 54, no. 2: 215-32. doi:10.1017/S0034412517000063.

Nagel, Thomas. 2010. Secular Philosophy and The Religious Temperament. Oxford: Oxford Univ. Press.

Scott, Michael. 2010. "Religious Language”. Philosophy Compass 5, no. 6: 505-15. doi:10.1111/j.1747-9991.2010.00301.x.

Scott, Michael, and Finlay Malcolm. forthcoming. "Religious Fictionalism". Philosophy Compass.

Szabó, Zoltán G. 2011. "Critical Study of Mark Eli Kalderon (ed.) Fictionalism in Mataphysics”. Noûs 45, no. 2: 375-85. doi:10.1111/j.1468-0068.2011.00828.x.

Whitehead, Alfred N. 1967. Science and the Modern World. New York, NY: Free Press. 